\title{
HUBUNGAN POLA MAKAN, ASUPAN MAKANAN DAN OBESITAS SENTRALDENGAN HIPERTENSI DI PUSKESMAS RAJABASA INDAH BANDAR LAMPUNG
}

\author{
Bertalina, Muliani \\ Jurusan Gizi Poltekkes Tanjungkarang \\ Email: ubertalina@yahoo.com
}

\begin{abstract}
Relationship Diet, Food Intake and Central Obesity with Hypertension in Health Center Indah Rajabasa Bandar Lampung. Hypertension contributes to heart disease, kidney failure, stroke, premature death and disability. At this time hypertension is the third largest risk factors that lead to premature death. The disease has killed 9.4 million people in the world each year. The World Health Organization (WHO)estimates that the number of hypertension will increase along with the number of population increases. In 2025 , projected at around $29 \%$ or about 1.6 billion people worldwide have hypertension. General purpose of this study to determine the relationship of diet, food intake and central obesity with blood pressure in hypertensive patients at health centers Rajabasa Indah Bandar Lampung. Quantitative research with analytic study design was cross sectional. Sample in this study are hypertension patients whovisited the health center Rajabasa Indah within 1 month, taken by accidental sampling. Result research shows diet raised the risk of blood pressure is often consume biscuits, eggs and terasi were statistically significant with hypertension. Intake of foods that have a significant relationship with hypertension that is the intake of animal protein, cholesterol, saturated fatty acids intake, fiber intake, and intake of sodium. Central obesity also has a significant relationship with hypertension. The need for cooperation between doctor and nutritionist so that patients can be referred to a nutritional consultation services so that patients understand more about diet hypertension.
\end{abstract}

Keywords: Hypertension, Diet, Nutrition, Central obesity

\begin{abstract}
Abstrak: Hubungan Pola Makan, Asupan Makanan dan Obesitas Sentral dengan Hipertensi di Puskesmas Rajabasa Indah Bandar Lampung. Hipertensi memberikan kontribusi bagi penyakit jantung, gagal ginjal, stroke, kematian premature dan cacat. Pada saat ini hipertensi adalah faktor risiko ketiga terbesar yang menyebabkan kematian dini. Penyakit ini telah membunuh 9,4 juta warga dunia setiap tahunnya. Badan Kesehatan Dunia (WHO) memperkirakan jumlah hipertensi akan terus meningkat seiring dengan jumlah penduduk yang bertambah. Pada 2025 mendatang, diproyeksikan sekitar 29\% atau sekitar 1,6 miliar orang di seluruh dunia mengalami hipertensi. Tujuan Umum penelitian ini untuk mengetahui hubungan pola makan, asupan makanan dan obesitas sentral dengan tekanan darah pada pasien hipertensi di Puskesmas Rajabasa Indah Bandar Lampung. Jenis penelitian kuantitatif dengan desain studi analitik pendekatan cross sectional.Sampel adalah pasien hipertensi yang berkunjung ke Puskesmas Rajabasa Indah pada dalam waktu 1 bulan, yang diambil secara acidental sampling. Hasil penelitian menunjukkan Pola makan yang berisiko meningkatkan tekanan darah adalah sering mengkonsumsi biskuit, telur dan terasi dinyatakan signifikan secara statistik dengan hipertensi. Asupan makanan yang memiliki hubungan yang signifikan dengan hipertensi yaitu asupan protein hewani, kolesterol, asupan asam lemak jenuh, asupan serat, dan asupan natrium, obesitas sentral juga memiliki hubungan yang signifikan dengan hipertensi. Perlu adanya kerjasama antara dokter dengan ahli gizi supaya pasien dapat dirujuk ke pelayanan konsultasi gizi sehingga pasien lebih memahami tentang diet penyakit hipertensi.
\end{abstract}

Kata Kunci: Hipertensi, Pola makan, Asupan gizi, Obesitas sentral

Hipertensi memberikan kontribusi bagi penyakit jantung, gagal ginjal, stroke, kematian prematur, dan cacat. Hipertensi bertanggung jawab setidaknya $45 \%$ dari kematian akibat penyakit jantung dan $51 \%$ kematian akibat stroke. Tahun 2008, di seluruh dunia, sekitar $40 \%$ dari orang dewasa berusia $\geq 25$ tahun telah didiagnosis hipertensi, jumlah orang dengan kondisi ini naik dari 600 juta pada tahun 1980 menjadi 1 miliar pada tahun 2008. Prevalensi hipertensi tertinggi di daerah Afrika yaitu 46\% orang dewasa berusia 25 tahun dan di atas 25 tahun telah didiagnosis dengan hipertensi (World Health Organization, 2013).

Hipertensi di Asia, tercatat 38,4 juta jiwa menderita hipertensi pada tahun 2000 dan 
diprediksi akan menjadi 67,4 juta orang pada tahun 2025. Prevalensi tertinggi hipertensi di Asia Tenggara yaitu Vietnam (2004) mencapai $34,5 \%$ (Infokes, 2007).

Hipertensi merupakan faktor risiko primer penyakit jantung dan stroke. Pada saat ini hipertensi adalah faktor risiko ketiga terbesar yang menyebabkan kematian dini. Hipertensi menyebabkan $62 \%$ penyakit kardiovaskular dan $49 \%$ penyakit jantung. Penyakit ini telah membunuh 9,4 juta warga dunia setiap tahunnya. Badan Kesehatan Dunia (WHO) memperkirakan jumlah hipertensi akan terus meningkat seiring dengan jumlah penduduk yang membesar. Pada 2025 mendatang, diproyeksikan sekitar 29\% atau sekitar 1,6 miliar orang di seluruh dunia mengalami hipertensi (Candra, 2013).

Kematian akibat Penyakit Tidak Menular (PTM) di Indonesia cenderung mengalami peningkatan. Prevalensi hipertensi di Indonesia menurut Riset Kesehatan Dasar tahun 2013 berdasarkan wawancara meningkat dari 7,6\% pada tahun 2007 menjadi 9,5\% pada tahun 2013 dan berdasarkan hasil pengukuran pada umur $\geq 18$ tahun sebesar 25,8\%. Prevalensi hipertensi dibeberapa provinsi di Sumatera, yaitu Aceh berdasarkan wawancara sebesar $9,8 \%$ dan pengukuran sebesar $21,5 \%$, Sumatera Utara berdasarkan wawancara sebesar $6,7 \%$ dan pengukuran sebesar $24,7 \%$, dan prevalensi hipertensi di provinsi lainnya cenderung meningkat. Berdasarkan data Riskesdas tahun 2013 prevalensi hipertensi di Provinsi Lampung berdasarkan wawancara meningkat dari $6,6 \%$ pada tahun 2007 menjadi 7,4\% pada tahun 2013 dan berdasarkan pengukuran meningkat dari $24,1 \%$ menjadi $24,7 \%$ pada tahun 2013 .

Hipertensi merupakan salah satu faktor risiko utama gangguan jantung. Selain mengakibatkan gagal jantung, hipertensi dapat berakibat terjadinya gagal ginjal maupun penyakit serebrovaskular. Pada kebanyakan kasus, hipertensi terdeteksi saat pemeriksaan fisik karena alasan penyakit tertentu, sehingga sering disebut sebagai "silent killer". Tanpa disadari penderita mengalami komplikasi pada organorgan vital seperti jantung, otak, ataupun ginjal (Depkes RI, 2006).

Banyak faktor yang dapat menyebabkan terjadinya hipertensi. Faktor risiko hipertensi antara lain adalah: faktor genetik, umur, jenis kelamin, etnis, stress, obesitas/ kegemukan, asupan garam, asupan kolesterol tinggi, makanan yang diawetkan, daging kambing, buah durian, kopi dan kebisaaan merokok. Selain usia dan faktor genetik, faktor lainnya dapat dikendalikan atau dihindari dengan pengontrolan pola hidup sehat, seperti diet rendah garam dan rendah lemak, hindari rokok dan alkohol, menghindari stres dan berolahraga sesuai kebutuhan menurunkan berat badan bagi yang kegemukan. Buah dan sayur merupakan sumber serat yang dapat membantu menurunkan tekanan darah tinggi. Obesitas/kegemukan mempunyai korelasi positif dengan hipertensi. Makin besar massa tubuh, makin banyak darah yang dibutuhkan untukmemasok oksigen dan makanan ke jaringan tubuh. Ini berarti bahwa volume darah yang beredar melalui pembuluh darah menjadi meningkat sehingga memberi tekanan lebih besar pada dinding arteri (AS, 2010).

Kebiasaan mengonsumsi lemak jenuh erat kaitannya dengan peningkatan berat badan yang berisiko terjadinya hipertensi. Konsumsi lemak jenuh juga meningkatkan risiko aterosklerosis yang berkaitan dengan kenaikan tekanan darah (AS, 2010). Sumber lemak jenuh banyak terdapat pada protein hewani, apabila asupan protein hewani berlebih cenderung dapat meningkatkan kadar kolesterol darah (Azwar, 2004). Penelitian Ariyanti (2005) menyatakan ada hubungan konsumsi natrium dengan tekanan darah.

Berdasarkan penelitian Widyaningrum (2012) diketahui antara asupan lemak dengan tekanan darah terdapat hubungan positif yang berarti semakin banyak asupan lemak maka akan semakin tinggi tekanan darah sistoliknya. Hasil penelitian Marisca (2013) tentang hubungan obesitas sentral dengan tekanan darah pasien penyakit jantung koroner menunjukkan hasil bahwa obesitas sentral mempunyai hubungan yang signifikan dengan tekanan darah pasien dengan nilai $p$ value $=0,001$. Obesitas sentral $/$ abdominal dapat diketahui melalui indikator rasio lingkar pinggang dan panggul (RLPP). Obesitas terutama tipe sentral/ abdominal sering dihubungkan dengan beberapa keadaan seperti diabetes melitus, hiperlipidemia, penyakit jantung, hipertensi, penyakit hepatobiliar dan peningkatan resiko mortalitas dan morbiditas (WHO 2002 dalam Riskesdas 2007).

Secara nasional, prevalensi obesitas sentral adalah $26.6 \%$, lebih tinggi dari prevalensi pada tahun 2007 (18,8\%). Sedangkan di provinsi Lampung prevalensi obesitas meningkat di tahun 2013 yaitu sebesar 19,8\%, yang pada tahun 2007 prevalensinya sebesar 14,5\% (Riskesdas, 2013).

Obesitas erat kaitannya dengan kadar lemak yang berlebihan di dalam tubuh. Jika makanan yang dimakan banyak mengandung lemak jahat (seperti kolesterol), dapat menyebabkan penimbunan lemak kolesterol di sepanjang pembuluh darah (AS, 2010). Penumpukan lemak tersebut dapat menyebabkan 
pembuluh darah menyempit, jaringan lemak akan menekan pembuluh darah, sehingga tidak bisa mengembang secara sempurna (kurang elastis). Dampaknya aliran darah ke seluruh tubuh pun terganggu.Hal ini memaksa jantung memompa darah lebih keras, sehingga tekanan darah meningkat dan terjadilah penyakit hipertensi (Khasanah, 2012).

Menurut Sutanto (2010), makanan yang banyak mengandung serat sangat penting untuk keseimbangan kadar kolesterol. Selain dapat menurunkan kadar kolesterol karena bermanfaat untuk mengangkut asam empedu, serat juga dapat mengatur kadar gula darah dan menurunkan tekanan darah.

Menurut Data Dinas Kesehatan Bandar Lampung, hipertensi termasuk dalam 5 besar penyakit terbanyak. Menurut Riskesdas 2013 prevalensi hipertensi di Provinsi Lampung berdasarkan pengukuran menunjukkan peningkatan dari $24,1 \%$ pada tahun 2007 menjadi $24,7 \%$ pada tahun 2013. Menurut data Dinas Kesehatan Bandar Lampung tahun 2013, total kunjungan penderita hipertensi di Puskesmas Kota Bandar Lampung sebanyak 2003 orang dengan kunjungan tertinggi di Puskesmas Rajabasa Indah.

Berdasarkan data yang diperoleh dari Puskesmas Raja Basa Indah, hipertensi merupakan salah satu jenis penyakit terbanyak yang diderita pasien. Prevalensi hipertensi di Puskesmas Rajabasa Indah pada tahun 2014 berada di posisi 2 dari 10 penyakit terbanyak dengan jumlah kunjungan sebanyak 993 orang.

Berdasarkan latar belakang tersebut peneliti tertarik untuk melakukan penelitian dengan judul: "Hubungan Pola Makan, Asupan Makanan dan Obesitas Sentral dengan Hipertensi di Puskesmas Rajabasa Indah Bandar Lampung Tahun 2015".

\section{METODE}

Jenis penelitian analitik dengan rancangan penelitian cross sectional yaitu suatu penelitian untuk mempelajari dinamika korelasi antara faktor-faktor resiko baik dengan efek, cara pendekatan, observasi ataupun pengumpulan data sekaligus pada satu saat (point time approach) .

Dalam penggunaan studi cross sectional pengukuran variabel dependen (tekanan darah pada pasien hipertensi) dan variabel independen (pola makan, asupan protein hewani, kolesterol, lemak jenuh, natrium, serat dan obesitas sentral) dilakukan pada waktu yang bersamaan dan secara langsung.
Populasi dalam penelitian adalah keseluruhan objek penelitian atau objek yang diteliti (Notoatmodjo, 2010). Populasi dalam penelitian ini adalah rata-rata pasien hipertensi usia $\geq 18$ tahun yang berobat di Puskesmas Rajabasa Indah. Jumlah populasi pasien hipertensi yang berobat di Puskesmas Rajabasa Indah tahun2014 adalah sebanyak 993 orang. Apabila dirata-ratakan jumlah populasi setiap bulannya ada sebanyak 91 orang. Sampel penelitian ini adalah pasien rawat jalan yang menderita hipertensi di Puskesmas Rajabasa Indah Bandar Lampung tahun 2015. Sampel pada penelitian ini ditentukan berdasarkan pertimbangan peneliti dengan menggunakan kriteria inklusi.

\section{HASIL}

\section{Analisis Univariat}

\section{a. Distribusi Tekanan Darah Pasien Hipertensi}

Distribusi tekanan darah pada pasien hipertensi dapat dilihat pada tabel 1:

Tabel 1. Distribusi Tekanan Darah pada
\begin{tabular}{lcc}
\multicolumn{2}{c}{ Pasien Hipertensi } \\
\hline \multirow{2}{*}{ Tekanan Darah } & \multicolumn{2}{c}{ Jumlah } \\
\cline { 2 - 3 } & $\mathrm{n}$ & $\%$ \\
\hline Tinggi & 50 & 66,7 \\
Sedang & 25 & 33,3 \\
$\quad$ Jumlah & 75 & 100 \\
\hline
\end{tabular}

Berdasarkan tabel 1 dapat diketahui bahwa tekanan darah paling banyak pada pasien adalah tekanan darah tinggi yang berjumlah 50 orang dengan presentase $66,7 \%$ dan pasien yang memiliki tekanan darah normal sebanyak 25 orang dengan persentase $33,3 \%$.

\section{b. Distibusi Pola Makan Berisiko}

\section{1) Pola Makan Sumber Makanan Pokok}

Pada tabel 2 di bawah, terlihat bahwa responden $74,7 \%$ masing sering mengkonsumsi roti, $68 \%$ sering mengkonsumsi gorengan, 38,75 sering mengkonsumsi kue bolu, dan 38,7\% sering mengkonsumsi biskuit dan $28 \%$ sering mengkonsumsi mie, $20 \%$ sering mengkonsumsi keripik singkong dan $17,3 \%$ sering mengkonsumsi krakers. 
Tabel 2. Pola Makan Sumber Makanan Pokok pada Pasien Hipertensi

\begin{tabular}{lcccccc}
\hline $\begin{array}{l}\text { Jenis } \\
\text { Makanan }\end{array}$ & Jarang & $\%$ & Sering & $\%$ & Total & $\%$ \\
\hline Mie & 54 & 72.0 & 21 & 28.0 & 75 & 100 \\
Roti & 19 & 25.3 & 56 & 74.7 & 75 & 100 \\
Biskuit & 46 & 61,3 & 29 & 38,7 & 75 & 100 \\
Krakers & 62 & 82.7 & 13 & 17.3 & 75 & 100 \\
Cake & 71 & 94,7 & 4 & 5,3 & 75 & 100 \\
Kue Bolu & 46 & 61,3 & 29 & 38,7 & 75 & 100 \\
$\begin{array}{l}\text { Gorengan } \\
\text { Kerpk }\end{array}$ & 24 & 32 & 51 & 68 & 75 & 100 \\
$\begin{array}{l}\text { singkong } \\
\text { Keripik }\end{array}$ & 60 & 80 & 15 & 20 & 75 & 100 \\
pisang & 62 & 82,7 & 13 & 17,3 & 75 & 100 \\
\hline
\end{tabular}

2) Pola Makan Sumber Makanan Protein Hewani dan Nabati

Tabel 3. Pola Makan Sumber Protein Hewani dan Nabati pada Pasien Hipertensi

\begin{tabular}{|c|c|c|c|c|c|c|}
\hline $\begin{array}{l}\text { Jenis } \\
\text { Makanan }\end{array}$ & Jarang & $\%$ & Sering & $\%$ & Total & $\%$ \\
\hline $\begin{array}{l}\text { Daging } \\
\text { bebek }\end{array}$ & 73 & 97,3 & 2 & 2,7 & 75 & 100 \\
\hline $\begin{array}{l}\text { Daging } \\
\text { sapi }\end{array}$ & 74 & 98,7 & 1 & 1,3 & 75 & 100 \\
\hline $\begin{array}{l}\text { Daging } \\
\text { kambing }\end{array}$ & 75 & 100 & 0 & 0 & 75 & 100 \\
\hline $\begin{array}{l}\text { Ayam } \\
\text { berlemak }\end{array}$ & 27 & 36 & 48 & 64 & 75 & 100 \\
\hline $\begin{array}{l}\text { Kuning } \\
\text { Telur }\end{array}$ & 54 & 72 & 21 & 28 & 75 & 100 \\
\hline Kornet & 73 & 97,3 & 2 & 2,7 & 75 & 100 \\
\hline Sosis & 70 & 93,3 & 5 & 6,7 & 75 & 100 \\
\hline Keju & 72 & 96 & 3 & 4 & 75 & 100 \\
\hline Susu & 35 & 46,7 & 40 & 53,3 & 75 & 100 \\
\hline Ikan asin & 52 & 69,3 & 23 & 30,7 & 75 & 100 \\
\hline Telur & 15 & 20 & 60 & 80 & 75 & 100 \\
\hline Jeroan & 75 & 100 & 0 & 0 & 75 & 100 \\
\hline $\begin{array}{l}\text { Tempe } \\
\text { goreng }\end{array}$ & 1 & 1,3 & 74 & 98,7 & 75 & 100 \\
\hline $\begin{array}{l}\text { Tahu } \\
\text { goreng }\end{array}$ & 1 & 1,3 & 74 & 98,7 & 75 & 100 \\
\hline $\begin{array}{l}\text { Keripik } \\
\text { tempe }\end{array}$ & 72 & 96 & 3 & 4 & 75 & 100 \\
\hline
\end{tabular}

Tabel 3 menunjukkan bahwa untuk makanan sumber protein responden sering mengkonsumsi tempe goreng $98,7 \%$, sering mengkonsumsi tahu goreng 98,7\%, sering mengkonsumsi telur $80 \%$, sering mengkonsumsi ayam berlemak $64 \%$, susu $53,3 \%$, ikan asin 30,7 dan kuning telur $28 \%$.
Tabel 4. Pola Makan Bahan Makanan Sayur dan Buah pada Pasien Hipertensi

\begin{tabular}{lcccccc}
\hline Jenis & Jarang & $\%$ & Sering & $\%$ & Total & $\%$ \\
Makanan & & & & & & \\
\hline $\begin{array}{l}\text { Durian } \\
\text { Asinan }\end{array}$ & 74 & 98,7 & 1 & 1,3 & 75 & 100 \\
$\begin{array}{l}\text { sayur } \\
\begin{array}{l}\text { Sayur } \\
\text { kalengan }\end{array}\end{array}$ & 75 & 96 & 3 & 4 & 75 & 100 \\
$\begin{array}{l}\text { Asinan } \\
\text { buah }\end{array}$ & 73 & 97,3 & 2 & 2,7 & 75 & 100 \\
\hline
\end{tabular}

Tabel 4, menunjukkan bahwa untuk bahan makanan yang bersumber dari buah dan sayur yang berisiko meningkatkan tekanan darah seperti asinan sayur dan asinan buah jarang dikonsumsi.

Tabel 5. Pola Makan Bumbu Pada Pasien Hipertensi

\begin{tabular}{lcccccc}
\hline $\begin{array}{l}\text { Jenis } \\
\text { Makanan }\end{array}$ & Jarang & $\%$ & Sering & $\%$ & Total & $\%$ \\
\hline $\begin{array}{l}\text { Saos } \\
\text { sambal }\end{array}$ & 56 & 74,7 & 19 & 25,3 & 75 & 100 \\
Saos & 57 & 76 & 18 & 24 & 75 & 100 \\
tomat & & & & & & \\
Terasi & 22 & 29,3 & 53 & 70,7 & 75 & 100 \\
Kecap & 26 & 34,7 & 49 & 65,3 & 75 & 100 \\
\hline
\end{tabular}

Tabel 5 terlihat bahwa $70,7 \%$ responden sering mengkonsumsi terasi, $65,3 \%$ mengkonsumsi kecap, 25,3\% mengkonsumsi saos sambal dan $24 \%$ mengkonsumsi saos tomat.

\section{c. Distribusi Asupan Makanan}

Distribusi Asupan Makanan yang meliputi: asupan protein hewani, lemk jenuh, kolesterol,natrium dan serat dapat dilihat pada tabel 6.

Asupan protein hewani merupakan jumlah asupan makanan dan minuman yang dikonsumsi pasien dalam berat bersih yang mengandung protein hewani selama dua puluh empat jam.Distribusi pasien berdasarkan jumlah asupan protein hewani diketahui bahwa asupan protein hewani kurang baik berjumlah 39 orang dengan presentase $52 \%$ dan asupan protein hewani baik berjumlah 36 orang dengan presentase $48 \%$.

Asupan asam lemak jenuh merupakan jumlah asupan makanan dan minuman yang dikonsumsi pasien dalam berat bersih yang mengandung asam lemak jenuh selama dua puluh empat jam. Asupan asam lemak jenuh pada pasien hipertensi yang kurang baik berjumlah 40 orang dengan presentase $53,3 \%$ dan asupan asam lemak jenuh yang baik berjumlah 35 orang dengan persentase $46,7 \%$.

Asupan kolesterol responden sudah baik, yaitu dengan presentase 59 orang $(78,7 \%)$. 
Sedangkan yang asupan kolesterolnya kurang baik 16 orang $(21,3 \%)$. Hasil recall hanya $18,7 \%$ pasien yang konsumsi natriumnya kurang baik. Sedangkan untuk asupan serat, sebagian besar asupan serat responden tidak cukup, yaitu dengan presentase $96 \%$ atau sejumlah 72 orang. Sedangkan jumlah responden yang asupan seratnya cukup sebanyak 3 orang (4\%).

\section{Tabel 6. Distribusi Asupan Makanan pada} Pasien Hipertensi

\begin{tabular}{lcc}
\hline \multirow{2}{*}{ Variabel } & \multicolumn{2}{c}{ Jumlah } \\
\cline { 2 - 3 } & $\mathrm{n}$ & $\%$ \\
\hline Asupan Protein Hewani & & 52 \\
Kurang baik & 39 & 48 \\
Baik & 36 & \\
\hline Asupan Lemak Jenuh & & 53,3 \\
Kurang baik & 40 & 46,7 \\
Baik & 35 & \\
\hline Asupan Kolesterol & & 50,7 \\
Kurang Baik & 38 & 49,3 \\
Baik & 37 & 18,7 \\
\hline Asupan Natrium & & 81,3 \\
Kurang baik & 14 & \\
Baik & 61 & 86,7 \\
\hline Asupan Serat & & 13,3 \\
Tidak Cukup & 65 & \\
Cukup & 10 & \\
\hline
\end{tabular}

\section{d. Gambaran Status Obesitas Sentral Pasien}

Distribusi pasien berdasarkan status obesitas sentral menurut besarnya lingkar perut responden dapat dilihat pada tabel 7 .

\section{Tabel 7. Distribusi Status Obesitas Sentral Pasien Hipertensi}

\begin{tabular}{lcc}
\hline \multirow{2}{*}{\multicolumn{1}{c}{ Status Gizi }} & \multicolumn{2}{c}{ Jumlah } \\
\cline { 2 - 3 } & n & \% \\
\hline Obesitas Sentral & 42 & 56 \\
Tidak Obesitas Sentral & 33 & 44 \\
\hline
\end{tabular}

Berdasarkan tabel 7 dapat diketahui bahwa sebagian besar responden yang memiliki ukuran lingkar perut lebih dari standar presentasenya lebih besar yaitu $56 \%$ (42 orang). Sedangkan responden dengan lingkar perut tidak melebihi batas presentasenya $44 \%$ (33 orang).

\section{Analisis Bivariat}

\section{a. Hubungan Pola Konsumsi dengan Hipertensi}

Untuk melihat adanya hubungan konsumsi makanan khas Lampung, maka dilihat makanan yang sering dikonsumsi yang berisiko meningkatkan tekanan darah yaitu seperti mie, roti, terasi.
Hubungan pola konsumsi makanan sumber makanan pokok yang berisiko menaikkan tenakan darah atau hipprtensi, yaitu mie, roti dan biskuit dapat dilihat pada tabel 8 berikut:

Tabel 8. Hubungan Pola Konsumsi dengan Hipertensi

\begin{tabular}{|c|c|c|c|c|c|c|c|}
\hline \multirow{3}{*}{ Variabel } & \multicolumn{4}{|c|}{ Hipertensi } & \multirow{2}{*}{\multicolumn{2}{|c|}{ Total }} & \multirow[t]{3}{*}{$p$ value } \\
\hline & \multicolumn{2}{|c|}{ Berat } & \multicolumn{2}{|c|}{ Ringan } & & & \\
\hline & $\mathrm{n}$ & $\%$ & $\mathrm{n}$ & $\%$ & $\mathrm{n}$ & $\%$ & \\
\hline \multicolumn{8}{|c|}{ Konsumsi Mie } \\
\hline Sering & 40 & 71,4 & 16 & 28,6 & 56 & 100 & \multirow[t]{3}{*}{0,222} \\
\hline Jarang & 10 & 52,6 & 9 & 47,4 & 19 & 100 & \\
\hline Jumlah & 50 & 66,7 & 25 & 33,3 & 75 & 100 & \\
\hline \multicolumn{8}{|c|}{ Konsumsi Roti } \\
\hline Sering & 12 & 57,1 & 9 & 42,9 & 21 & 100 & \multirow[t]{3}{*}{0,413} \\
\hline Jarang & 38 & 70,4 & 16 & 29,6 & 54 & 100 & \\
\hline Jumlah & 50 & 66,7 & 25 & 33,3 & 75 & 100 & \\
\hline \multicolumn{8}{|c|}{ Konsumsi Biskuit } \\
\hline Sering & 34 & 81,0 & 8 & 19,0 & 42 & 100 & \multirow[t]{3}{*}{0,007} \\
\hline Jarang & 16 & 48,5 & 17 & 51,5 & 33 & 100 & \\
\hline Jumlah & 50 & 66,7 & 25 & 33,3 & 75 & 100 & \\
\hline \multicolumn{8}{|c|}{ Konsumsi Gorengan } \\
\hline Sering & 31 & 60,8 & 20 & 39,2 & 51 & 100 & \multirow[t]{3}{*}{0,189} \\
\hline Jarang & 19 & 79,2 & 5 & 20,8 & 24 & 100 & \\
\hline Jumlah & 50 & 66,7 & 25 & 33,3 & 75 & 100 & \\
\hline
\end{tabular}

Berdasarkan tabel 8 dapat diketahui bahwa pasien dengan yang sering mengkonsumsi mie dan mengalami hipertensi berat sebanyak 12 $(57,1 \%)$ dan responden yang jarang mengkonsumsi mie dan mengalami hipertensi berat sebanyak $38 \quad(70,4 \%)$. Hasil uji statistik diperoleh nilai $\mathrm{p}$ sebesar 0,431 (lebih besar dari nilai alpha $=0,050$ ) yang berarti Ho ditterima sehingga dapat disimpulkan tidak ada hubungan yang signifikan antara sering mengkonsumsi mie dengan hipertensi berat.

Pasien yang sering mengkonsumsi roti mengalami hipertensi berat sebanyak $40(71,4 \%)$ dan responden dengan pola konsumsi jarang mengkonsumsi roti mengalami hipertensi berat sebanyak 10 (52,6\%). Hasil uji statistik diperoleh nilai $p$ value sebesar 0,222 (lebih besar dari nilai alpha 0,050 ) yang berarti Ho diterima sehingga dapat disimpulkan tidak ada hubungan yang signifikan antara pola konsumsi roti dengan tekanan darah pasien hipertensi rawat jalan di Puskesmas Rajabasa Indah Kota Bandar Lampung Tahun 2015.

Pasien yang sering mengkonsumsi biskuit dan mengalami hipertensi berat sebanyak 34 $(81,0 \%)$ dan responden dengan pola konsumsi jarang mengkonsumsi biskuit yang mengalami hipertensi berat sebanyak $10 \quad(48,56 \%)$. Hasil uji statistik diperoleh nilai $p$ value sebesar 0,007 (lebih kecil dari nilai alpha 0,050) yang berarti Ho ditolak sehingga dapat disimpulkan ada hubungan yang signifikan antara pola konsumsi 
biskuit dengan hipertensi pada pasien hipertensi rawat jalan di Puskesmas Rajabasa Indah Kota Bandar Lampung Tahun 2015.

Pasien yang sering mengkonsumsi gorengan dan mengalami hipertensi berat sebanyak $31(60,8 \%)$ dan responden dengan pola konsumsi jarang mengkonsumsi gorengan yang mengalami hipertensi berat sebanyak 19 (79.2\%). Hasil uji statistik diperoleh nilai $p$ value sebesar 0,189 (lebih besar dari nilai alpha 0,050) yang berarti Ho diterima sehingga dapat disimpulkan tidak ada hubungan yang signifikan antara pola konsumsi gorengan dengan hipertensi pada pasien hipertensi rawat jalan di Puskesmas Rajabasa Indah Kota Bandar Lampung Tahun 2015.

Hubungan pola konsusmsi makanan sumber protein hewani yang berisiko terhadap hipertensi seperti ayam berlemak, telur dan ikan asin dapat dilihat pada tabel dibawah ini :

Tabel 9. Hubungan Pola Konsumsi Protein Hewani dengan Hipertensi

\begin{tabular}{|c|c|c|c|c|c|c|c|}
\hline \multirow{3}{*}{ Variabel } & \multicolumn{4}{|c|}{ Hipertensi } & \multicolumn{2}{|c|}{ Total } & \multirow{3}{*}{$\begin{array}{c}p \\
\text { value }\end{array}$} \\
\hline & \multicolumn{2}{|c|}{ Berat } & \multicolumn{2}{|c|}{ Ringan } & \multirow[b]{2}{*}{$\mathrm{n}$} & \multirow[b]{2}{*}{$\%$} & \\
\hline & $\mathrm{n}$ & $\%$ & $\mathrm{n}$ & $\%$ & & & \\
\hline \multicolumn{8}{|c|}{ Konsumsi Ayam berlemak } \\
\hline Sering & 34 & 70,8 & 14 & 29,2 & 48 & 100 & 0,586 \\
\hline Jarang & 16 & 59,3 & 11 & 40,7 & 37 & 100 & \\
\hline Jumlah & 50 & 66,7 & 25 & 33,3 & 75 & 100 & \\
\hline \multicolumn{8}{|c|}{ Konsumsi Telor } \\
\hline Sering & 44 & 73,3 & 16 & 26,7 & 60 & 100 & 0,032 \\
\hline Jarang & 6 & 40,0 & 9 & 60,0 & 15 & 100 & \\
\hline Jumlah & 50 & 66,7 & 25 & 33,3 & 75 & 100 & \\
\hline \multicolumn{8}{|c|}{ Konsumsi Ikan Asin } \\
\hline Sering & 16 & 69,6 & 7 & 30,4 & 23 & 100 & 0,929 \\
\hline Jarang & 34 & 65,4 & 18 & 34,6 & 42 & 100 & \\
\hline Jumlah & 50 & 66,7 & 25 & 33,3 & 75 & 100 & \\
\hline \multicolumn{8}{|c|}{ Konsumsi Terasi } \\
\hline Sering & 41 & 77,4 & 12 & 22,6 & 53 & 100 & 0,005 \\
\hline Jarang & 9 & 40,9 & 13 & 59,1 & 22 & 100 & \\
\hline Jumlah & 50 & 66,7 & 25 & 33,3 & 75 & 100 & \\
\hline
\end{tabular}

Berdasarkan tabel 9 dapat diketahui bahwa pasien yang sering mengkonsumsi ayam berlemak dan mengalami hipertensi berat sebanyak $34(70,8 \%)$ dan responden dengan pola konsumsi jarang mengkonsumsi ayam berlemak yang mengalami hipertensi berat sebanyak 16 (59.3\%). Hasil uji statistik diperoleh nilai $p$ value sebesar 0,586 (lebih besar dari nilai alpha 0,050) yang berarti Ho diterima sehingga dapat disimpulkan tidak ada hubungan yang signifikan antara pola konsumsi ayam berlemak dengan hipertensi pada pasien hipertensi rawat jalan di Puskesmas Rajabasa Indah Kota Bandar Lampung Tahun 2015.

Bahwa pasien yang sering mengkonsumsi telur dan mengalami hipertensi berat sebanyak
44(73,3\%) dan responden dengan pola konsumsi jarang mengkonsumsi telur yang mengalami hipertensi berat sebanyak $6(40,0 \%)$. Hasil uji statistik diperoleh nilai $p$ value sebesar 0,032 (lebih kecil dari nilai alpha 0,050) yang berarti Ho ditolak sehingga dapat disimpulkan ada hubungan yang signifikan antara pola konsumsi telur dengan hipertensi pada pasien hipertensi rawat jalan di Puskesmas Rajabasa Indah Kota Bandar Lampung Tahun 2015.

Pasien yang sering mengkonsumsi ikan asin dan mengalami hipertensi berat sebanyak 16 $(69,6 \%)$ dan responden dengan pola konsumsi jarang mengkonsumsi telur yang mengalami hipertensi berat sebanyak 34 (65,4\%). Hasil uji statistik diperoleh nilai $p$ value sebesar 0,929 (lebih besar dari nilai alpha 0,050) yang berarti Ho diterima sehingga dapat disimpulkantidak ada hubungan yang signifikan antara pola konsumsi ikan asin dengan hipertensi pada pasien hipertensi rawat jalan di Puskesmas Rajabasa Indah Kota Bandar Lampung Tahun 2015. Untuk golongan bumbu bahan makanan yang sering dikonsumsi adalah saus dan terasi.

Pasien yang sering mengkonsumsi terasi dan mengalami hipertensi berat sebanyak 41 $(77,4 \%)$ dan responden dengan pola konsumsi jarang mengkonsumsi terasi yang mengalami hipertensi berat sebanyak $9(40,9 \%)$. Hasil uji statistik diperoleh nilai $p$ value sebesar 0,005 (lebih kecil dari nilai alpha 0,050) yang berarti Ho ditolak sehingga dapat disimpulkan ada hubungan yang signifikan antara pola konsumsi terasi dengan hipertensi pada pasien hipertensi di Puskesmas Rajabasa Indah Kota Bandar Lampung Tahun 2015.

\section{b. Hubungan Asupan Makanan dan Obesitas Sentral dengan Hipertensi}

\section{1) Hubungan Protein Hewani dengan Tekanan Darah}

Berdasarkan tabel 10 dapat diketahui bahwa pasien dengan asupan protein hewani kurang baik mengalami hipertensi berat sebanyak $33(84,6 \%)$ dan responden dengan asupan protein hewani baik mengalami hipertensi berat sebanyak 17 (47,2\%). Hasil uji statistik diperoleh nilai $p$ value sebesar 0,001 (lebih kecil dari nilai alpha= 0,050) yang berarti Ho ditolak sehingga dapat disimpulkan ada hubungan yang signifikan antara asupan protein hewani dengan tekanan darah pasien hipertensi di Puskesmas Rajabasa Indah Kota Bandar Lampung Tahun 2015. 
Tabel 10. Hubungan Asupan Makanan dan Obesitas Sentral dengan Hipertensi

\begin{tabular}{|c|c|c|c|c|c|c|c|}
\hline \multirow{3}{*}{ Variabel } & \multicolumn{4}{|c|}{ Hipertensi } & \multirow{2}{*}{\multicolumn{2}{|c|}{ Total }} & \multirow{3}{*}{ p value } \\
\hline & \multicolumn{2}{|c|}{ Berat } & \multicolumn{2}{|c|}{ Ringan } & & & \\
\hline & $\mathrm{n}$ & $\%$ & $\mathrm{n}$ & $\%$ & $\mathrm{n}$ & $\%$ & \\
\hline \multicolumn{8}{|c|}{ Asupan Protein Hewani } \\
\hline $\begin{array}{l}\text { Kurang } \\
\text { baik }\end{array}$ & 33 & 84,6 & 6 & 15,4 & 39 & 100 & \multirow[t]{3}{*}{0,001} \\
\hline Baik & 17 & 47,2 & 19 & 52,8 & 36 & 100 & \\
\hline Jumlah & 50 & 66,7 & 25 & 33,3 & 75 & 100 & \\
\hline \multicolumn{8}{|c|}{ Asupan Asam Lemak Jenuh } \\
\hline $\begin{array}{l}\text { Kurang } \\
\text { baik }\end{array}$ & 34 & 85 & 6 & 15 & 40 & 100 & \multirow[t]{3}{*}{0,001} \\
\hline Baik & 16 & 45,7 & 19 & 54,3 & 35 & 100 & \\
\hline Jumlah & 50 & 66,7 & 25 & 33,3 & 75 & 100 & \\
\hline \multicolumn{8}{|c|}{ Asupan Kolesterol } \\
\hline $\begin{array}{l}\text { Kurang } \\
\text { baik }\end{array}$ & 30 & 78,9 & 8 & 21,1 & 38 & 100 & \multirow[t]{3}{*}{0,041} \\
\hline Baik & 20 & 54,1 & 17 & 45,9 & 37 & 100 & \\
\hline Jumlah & 50 & 66,7 & 25 & 33,3 & 75 & 100 & \\
\hline \multicolumn{8}{|c|}{ Asupan serat } \\
\hline $\begin{array}{l}\text { Tidak } \\
\text { cukup }\end{array}$ & 47 & 72,3 & 18 & 27,7 & 65 & 100 & \multirow[t]{3}{*}{0,013} \\
\hline Cukup & 3 & 30,0 & 7 & 70,0 & 10 & 100 & \\
\hline Jumlah & 50 & 66 & 25 & 33,3 & 75 & 100 & \\
\hline \multicolumn{8}{|c|}{ Asupan Natrium } \\
\hline $\begin{array}{l}\text { Kurang } \\
\text { baik }\end{array}$ & 13 & 92,9 & 1 & 7,1 & 72 & 100 & \multirow[t]{3}{*}{0,027} \\
\hline Baik & 37 & 60,7 & 24 & 39,3 & 3 & 100 & \\
\hline & 50 & 66,7 & 25 & 33,3 & 75 & 100 & \\
\hline \multicolumn{8}{|c|}{ Obesitas Sentral } \\
\hline $\mathrm{Ya}$ & 33 & 78,6 & 9 & 21,4 & 42 & 100 & \multirow[t]{3}{*}{0,026} \\
\hline Tidak & 17 & 51,5 & 16 & 16 & 33 & 100 & \\
\hline Jumlah & 50 & 66,7 & 25 & 33,3 & 75 & 100 & \\
\hline
\end{tabular}

\section{2) Hubungan Asupan Asam Lemak Jenuh} dengan Tekanan Darah

Berdasarkan tabel 10 dapat diketahui bahwa pasien dengan asupan asam lemak jenuh kurang baik mengalami hipertensi berat sebanyak $34(85 \%)$ dan pasien dengan asupan asam lemak jenuh baik mengalami hipertensi berat sebanyak 16 orang $(45,7 \%)$. Hasil uji statistik diperoleh nilai $p$ value sebesar 0,001 (lebih kecil dari nilai alpha $=0,050$ ) yang berarti Ho ditolak sehingga dapat disimpulkan bahwa ada hubungan yang signifikan antara asupan asam lemak jenuh dengan tekanan darah pada pasien hipertensi di Puskesmas Rajabasa Indah Kota Bandar Lampung.

\section{3) Hubungan Asupan Kolesterol Dengan Hipertensi}

Hasil analisis hubungan antara asupan kolesterol dengan hipertensi darah pasien diperoleh bahwa ada sebanyak $30 \quad(78,9 \%)$ responden yang asupan kolesterolnya kurang baik dengan hipertensi berat, sedangkan $20(54,1 \%)$ responden yang asupan kolesterolnya baik, mengalami hipertensi berat. Hasil uji statistik diperoleh $p$ value $=0,041$ yang menunjukkan ada hubungan yang signifikan antara asupan kolesterol dan tekanan darah.

\section{4) Hubungan Asupan Serat dengan Hipertensi \\ Hubungan antara asupan serat dengan} tekanan darah responden dapat dilihat pada tabel 10.

Hasil analisis hubungan antara asupan serat dengan tekanan darah diperoleh bahwa ada sebanyak $47(72,3 \%)$ responden yang asupan seratnya tidak baik menderita hipertensi berat, sedangkan $3(30,0 \%)$ responden yang asupan seratnya baik menderita hipertensi ringan. Hasil uji statistik diperoleh $p$ value $=0,013$ sehingga dapat disimpulkan ada hubungan yang signifikan antara asupan serat dan tekanan darah.

\section{5) Hubungan Asupan Natrium dengan Hipertensi \\ Hasil analisis hubungan antara asupan} natrium dengan hipertensi diperoleh bahwa ada sebanyak $13(92,9 \%)$ responden yang asupan natriumnya kurang baik dengan menderita hipertensi berat, sedangkan $37 \quad(60,7 \%)$ responden yang asupan natriumnya menderita hipertensi berat. Hasil uji statistik diperoleh $p$ value $=0,027$, sehingga dapat disimpulkan ada hubungan yang signifikan antara asupan natrium dan hipertensi.

\section{6) Hubungan Obesitas Sentral dengan Tekanan Darah}

Hasil analisis hubungan antara status obesitas sentral dengan tekanan darah diperoleh bahwa ada sebanyak $33(78,6 \%)$ responden yang mengalami obesitas sentral dengan hipertensi berat, sedangkan diantara $17(51,5 \%)$ responden yang tidak obesitas sentral,dengan hipertensi berat. hasil uji statistik diperoleh $p$ value $=0,026$ yang menunjukkan ada hubungan yang signifikann antara obesitas sentral dengan hipertensi.

\section{PEMBAHASAN}

\section{Gambaran Umum Responden}

Jenis kelamin responden dibedakan menjadi laki-laki dan perempuan.Sebagian besar pasien hipertensi yang menjadi sampel penelitian berjenis kelamin perempuan.Presentase tertinggi pasien hipertensi berdasarkan jenis kelamin adalah perempuan dengan presentase $92 \%$.

Jenis kelamin merupakan salah satu faktor yang dapat mempengaruhi hipertensi. Secara 
umum perempuan lebih banyak menderita hipertensi dibandingkan dengan laki-laki.Hal ini dipengaruhi oleh faktor psikologis.Perempuan sering kali mengadopsi perilaku tidak sehat seperti pola makan yang tidak seimbang sehingga menyebabkan kelebihan berat badan, depresi, dan rendahnya status pekerjaan (Sutanto, 2010).

Umur merupakan usia responden yang dilihat dari tanggal lahir responden. Sebagian besar pasien hipertensi yang menjadi sampel penelitian berusia lebih dari 40 tahun. Presentase tertinggi pasien hipertensi berdasarkan usia adalah pada kelompok umur 45-54 tahun dengan presentase $28 \%$.

Akibat bertambahnya usia dan proses penuaan, serabut kolagen di pembuluh darah dan dinding arterol bertambah sehingga dinding pembuluh tersebut mengeras. Berkurangnya elastisitas ini, mengakibatkan daerah yang dipengaruhi tekanan sistolik akan menyempit sehingga tekanan darah rata-ratameningkat (Azwar, Achdiat, dan Arizal, 2011).

Pendidikan merupakan kegiatan belajar mengajar yang dilakukan secara formal yang disahkan oleh Kementerian Pendidikan. Berdasarkan hasil analisis data pendidikan responden yang menjadi sampel penelitian diketahui 27 orang responden memiliki pendidikan terakhir adalah SMA/SLTA sederajat dengan presentase $36 \%$.

Semakin tinggi pendidikan seseorang semakin mudah mereka menerima informasi dan akhirnya semakin banyak pengetahuan yang dimilikinya. Sebaliknya jika seseorang tingkat pendidikannya rendah, akan menghambat perkembangan sikap seseorang terhadap penerimaan informasi dan nilai-nilai yang baru diperkenalkan (Mubarak, 2007).

Pekerjaan adalah tugas yang dilakukan setiap hari, dimana tugas yang dilakukan dijadikan sebagai penghidupan dan untuk mendapatkan nafkah. Presentase tertinggi pasien hipertensi berdasarkan pekerjaan adalah tidak bekerja atau ibu rumah tangga dengan presentase $50,7 \%$. Banyaknya responden yang tidak bekerja karena faktor usia dan sebagian besar responden berjenis kelamin perempuan. Selain itu, hal ini dikarenakan kebanyakan dari responden sudah tergolong ke dalam kelompok umur lansia.

Hal ini sesuai dengan penelitian Putra (2010) di wilayah Puskesmas Lapai Kecamatan Nanggalo Padang menunjukkan bahwa penderita penyakit hipertensi sebagaian besar tidak bekerja dengan presentase $84,4 \%$. Pekerjaan berpengaruh kepada aktivitas fisik seseorang. Orang yang tidak bekerja aktivitasnya tidak banyak sehingga dapat meningkatkan kejadian hipertensi (Handriani, 2009).

\section{Hubungan Pola Makan dengan Hipertensi}

Hubungan pola komsumsi dengan hipertensi, dilihat dari sumber bahan makanan pokok yang berisiko meningkatkan tekanan darah yaitu mie, roti, makanan gorengan (pisang goreng, bakwan dll) dan biskuit, namun dari hasil uji sttistik dari ketiga bahan makanan tersebut yang menunjukkan ada hubungan signifikan denga hipertensi hanya biskuit.

Beberapa bahan makan sumber protein hewani yangsering dikonsumsi dan berisiko meningkatkan tekanan darah yaitu ayam berlemak, telur, dan ikan asin. Hasil iji statistik menunjukkan bahwa telur memiliki hubungan yang signifikan manaikkan tekanan darah.

Bahan makanan yang digunakan sebagai bumbu dan sering dikonsumsi adalah saos sambal, saos tomat dan terasi, namun uji statistik menunjukkan bahwa konsumsi terasi berhubungan dengan meningkatnya tekanan darah pasien.

Penelitian Saban, dkk (2013), menunjukkan ada hubungan yang bermakna antara pola makan (jenis makanan) yang dikonsumsi dengan hipertensi. Hasil penelitian ini juga sesuai dengan penelitian Widyaningrum (2012), yang menyatakan ada hubungan makan makan yang memicu hipertersi yaitu telur asin.

\section{Hubungan Asupan Protein Hewani dengan Hipertensi}

Protein hewani merupakan salah satu faktor risiko terjadinya hipertensi.Konsumsi protein dalam makanan sehari-hari yang dianjurkan yaitu $1 / 3$ bagian protein yang dibutuhkan berasal dari protein hewani (Almatsier, 2009).

Berdasarkan hasil analisis data diketahui bahwa asupan protein hewani pada pasien hipertensi yang kurang baik mengalami tekanan darah tinggi sebanyak $84,6 \%$ dan asupan protein hewani baik mengalami tekanan darah tinggi sebanyak 47,2\%. Asupan protein hewani pasien yang kurang baik dikarenakan asupannya kurang $<90 \%$ dan lebih $>110 \%$ dri yang dianjurkan. Hal ini dikarenakan responden mengonsumsi makanan belum sesuai dengan diet yang dianjurkan seperti daging dan ikan maksimal 100 gram sehari dan telur maksimal 1 butir sehari.Perlu adanya peningkatan peran dan kerjasama seluruh tenaga kesehatan untuk memberikan pengetahuan mengenai penyakit 
hipertensi melalui konsultasi gizi terutama mengenai asupan zat gizi.Selain itu, dengan penambahan sarana informasi berupa poster yang ditempel di ruang tunggu atau leaflet yang diberikan kepada pasien setelah konsultasi, diharapkan pasien lebih memahami informasi terkait penyakit hipertensi terlebih mengenai pemberian diet.Bahan makanan yang mengandung protein hewani yang paling banyak dikonsumsi oleh responden adalah ayam, ikan kembung, dan telur.Berdasarkan hasil penelitian responden yang tekanan darahnya tinggi sejalan dengan asupan protein hewani yang kurang baik.

Hasil uji statistik, dinyatakan bahwa adanya hubungan yang signifikan antara asupan protein hewani dengan tekanan darah pada pasien hipertensi.Hal ini sesuai dengan penelitian yang dilakukan oleh Katulistiwa (2013) yang menunjukkan adanya hubungan antara konsumsi protein hewani (daging) dengan kolesterol dan aterosklerosis yang dapat menyebabkan terjadinya hipertensi. Hal tersebut disebabkan, kebiasaan mengonsumsi protein hewani melebihi asupan yang dianjurkan.Konsumsi sumber protein hewani dalam jumlah yang berlebihan dapat meningkatkan risiko tekanan darah, dikarenakan kandungan lemak jenuh dan kolesterolnya lebih tinggi daripada sumber protein nabati (Kurniawan, 2002).

\section{Hubungan Asupan Asam Lemak Jenuh dengan Hipertensi}

Asam lemak jenuh merupakan salah satu faktor risiko terjadinya hipertensi.Hal ini dikarenakan kebiasaan mengonsumsi lemak jenuh erat kaitannya dengan peningkatan berat badan yang berisiko terjadinya hipertensi.Konsumsi lemak jenuh juga meningkatkan risiko aterosclerosis yang berkaitan dengan kenaikan tekanan darah (AS, 2010).

Hasil analisis data asupan asam lemak jenuh diketahui bahwa dari 34 orang asupan asam lemak jenuh kurang baik mengalami tekanan darah tinggi dengan presentase $85 \%$ dan pasien dengan asupan asam lemak jenuh baik mengalami tekanan darah tinggi sebanyak 16 orang $(45,7 \%)$. Sumber lemak jenuh yang banyak dikonsumsi oleh responden dalam penelitian adalah minyak kelapa sawit, santan, dan lauk hewani seperti daging ayam dengan kulitnya.

Berdasarkan hasil uji statistik, dinyatakan bahwa terdapat hubungan yang signifikan antara asupan lemak jenuh dengan tekanan darah pasien hipertensi. Hal ini sesuai dengan penelitian Nugraheni, Suryandari, dan Aruben (2008) di
Puskesmas Semarang diketahui antara asupan lemak dengan tekanan darah terdapat hubungan positif yang berarti semakin banyak asupan lemak maka akan semakin tinggi tekanan darah sistoliknya. Penelitian ini juga sesuai dengan hasil penelitian Sugiharto (2007) di Karanganyar bahwa kebiasaan mengonsumsi lemak jenuh yaitu $\geq 3$ kali dalam seminggu terbukti sebagai faktor risiko yang berpengaruh terhadap kejadian hipertensi dengan nilai $p$ value $=0,024$.

Secara teoritis makanan yang berlemak dapat meningkatkan risiko hipertensi.Jenis lemak yang berbahaya terhadap peningkatan tekanan darah adalah jenis lemak jenuh yang terdapat pada bahan pangan hewani. Hal ini disebabkan lemak jenuh cenderung meningkatkan kadar kolesterol darah dan trigliserida Nugraheni, Suryandari, dan Aruben (2008).

\section{Hubungan Asupan Kolesterol dengan Hipertensi}

Berdasarkan hasil penelitian dapat diketahui bahwa sebagian besar asupan kolesterol responden sudah baik yaitu dengan presentase $78,7 \%$ atau dengan jumlah responden sebanyak 59 orang. Hasil dari 16 responden yang asupan kolesterolnya kurang baik terdapat 9 (56,2\%) responden dengan tekanan darah tinggi, sedangkan diantara 59 responden yang asupan kolesterolnya baik, terdapat 41 (69,5\%) responden yang tekanan darahnya tinggi. Jumlah asupan kolesterol yang dianjurkan dari bahan makanan adalah $\leq 300 \mathrm{mg} /$ hari (Almatsier, 2009).

Hasil uji statistik didapatkan $p$ value $=$ 0,041 yang menunjukkan hubungan yang signifikan antara asupan kolesterol dengan tekanan darah. Hal ini juga sejalan dengan hasil penelitian Agustina (2012) dimana dalam penelitiannya tentang uji korelasi antara asupan kolesterol dengan tekanan darah sistolik dan diastolik pasien hipertensi di Poli Penyakit dalam RSP Batu, tidak terdapat hubungan yang signifikan antara asupan kolesterol dengan tekanan darah sistolik dan diastolik. Sedangkan menurut Khasanah (2010), kolesterol diketahui sangat berpengaruh terhadap tekanan darah. Jumlah asupan kolesterol yang berlebih akan menempel pada dinding pembuluh darah, dan jika kadar kolesterol terus-menerus tinggi dalam darah, maka kolesterol yang menempel pada dinding pembuluh darah akan semakin banyak dan dapat menyebabkan penyempitan pembuluh darah. Penyempitan dan sumbatan lemak ini kemudian memacu jantung untuk memompa darah lebih kuat lagi, akibatnya tekanan darah 
menjadi meningkat.Sehingga hasil penelitian ini tidak sesuai dengan teori yang ada.

\section{Hubungan Asupan Serat dengan Hipertensi}

Menurut hasil penelitian, diketahui bahwa sebagian besar asupan serat responden tidak mencukupi yaitu dengan presentase $96 \%$ atau dengan jumlah responden sebanyak 72 orang. Dari dari 72 responden yang asupan seratnya tidak cukup terdapat $49(68,1 \%)$ responden dengan tekanan darah tinggi, sedangkan diantara 3 responden yang asupan seratnya baik, terdapat $1(33,3 \%)$ responden yang tekanan darahnya tinggi. Asupan serat responden yang sebagian besar tidak mencukupi ini kemungkinan disebabkan responden kurang konsumsi makanan sumber serat, seperti sayur, buah, dan biji-bijian atau dalam mengkonsumsi bahan makanan sumber serat porsinya kurang mencukupi.

Konsumsi serat yang dibutuhkan oleh tubuh sebesar 25 gram per hari (Almatsier, 2009). Menurut ADA (American Dietetic Association), National Cancer Institute, dan American Cancer Society, kebutuhan serat pada orang dewasa sekitar 25 - 35 gram atau 10 - 14 gram serat per 1000 kalori, setiap hari (Prakoso, 2012). Asupan tinggi serat terutama dalam bentuk serat larut berkaitan dengan pencegahan hipertensi.Apabila asupan serat rendah, maka dapat menyebabkan obesitas yang berdampak pada peningkatan tekanan darah dan penyakit degeneratif.

Hasil uji statistik diperoleh $p$ value $=0,256$ yang menunjukkan bahwa tidak ada hubungan yang signifikan antara asupan serat dan tekanan darah. Hal ini juga sejalan dengan hasil penelitian Apriany (2012) bahwa asupan serat pada subjek penelitian yaitu responden hipertensi sebagian besar <25 gram, dan secara statistik tidak menunjukkan keterkaitan antara asupan serat dengan tekanan darah sistolik maupun diastolik. Sedangkan menurut Astawan., Wresdiyati (2004), serat pangan mempunyai peranan penting dalam penurunan tekanan darah, yaitu dengan cara membantu menurunkan kadar kolesterol plasma dengan meningkatkan sekresi asam empedu melalui feses.

Di dalam usus, asam lemak yang dihasilkan dari pencernaan lemak akan diserap bersama asam empedu untuk diubah menjadi kolesterol yang diangkut ke seluruh tubuh dalam bentuk kilomikron. Dengan adanya asupan serat yang cukup, serat mampu mengikat asam (garam empedu) sehingga akan mencegah reabsorbsinya dari usus serta meningkatkan sekresi/ pengeluarannya melalui feses. Asupan serat yang sedikit, maka akan sedikit juga asam empedu yang diikat dan dikeluarkan melalui feses. Perlu diutarakan bahwa asam (garam) empedu mengandung banyak kolesterol dan merupakan saluran utama pembuangan kolesterol dari dalam tubuh (Astawan.,Wresdiyati., 2004).

Dalam penelitian ini menunjukkan adanya hubungan yang signifikan antara asupan serat dengan tekanan darah disebabkan sebagian besar responden asupan seratnya dalam sehari tidak mencukupi.Sehingga perlu diberikan konsultasi saat pasien berobat ke puskesmas tentang diet penyakit hipertensi serta informasi anjuran bahan makanan sumber serat yang perlu dikonsumsi dalam sehari.

\section{Hubungan Asupan natrium dengan Hipertensi}

Hasil penelitian menunjukkan bahwa asupan natrium dari hasil recall didapat hanya $18,7 \%$ yang konsumsinya tidak baik, namun jika dibandingkan dengan pola konsumsi tidak sejalan dimana responden $74,7 \%$ masih sering mengkonsumsi roti, $68 \%$ sering mengkonsumsi gorengan, 38,75 sering mengkonsumsi kue bolu, dan $38,7 \%$ sering mengkonsumsi biskuit dan $28 \%$ sering mengkonsumsi mie, $20 \%$ sering mengkonsumsi keripik singkong dan 17,3\% sering mengkonsumsi krakers. Hasil analisis hubungan diperoleh bahwa ada sebanyak 13 $(92,9 \%)$ responden yang asupan natriumnya kurang baik dengan menderita hipertensi berat, sedangkan $37(60,7 \%)$ responden yang asupan natriumnya menderita hipertensi berat.Hasil uji statistik diperoleh $p$ value $=0,027$, sehingga dapat disimpulkan ada hubungan yang signifikan antara asupan natrium dan hipatertensi. Hasil tersebut tidak berbeda dengan hasil Muliyati, $\mathrm{dkk}$, dimana ada hubungan yang signifikan antara konsumsi natrium dengan hipertensi dgn nilai $\mathrm{p}$ 0.000 .

\section{Hubungan Obesitas Sentral dengan Hipertensi}

Berdasarkan penelitian yang dilakukan di Puskesmas Rajabasa Indah, diketahui bahwa sebagian besar responden mengalami obesitas sentral yaitu dengan presentase $56 \%$ atau dengan jumlah responden sebanyak 42 orang. Dari 42 responden yang mengalami obesitas sentral terdapat $33(78,6 \%)$ responden yang tekanan darahnya tinggi. Sedangkan dari 33 responden yang tidak obesitas sentral terdapat 17 (51,5\%) responden yang tekanan darahnya tinggi. Menurut Khasanah (2012), seseorang yang 
mengalami obesitas sentral berisiko lebih tinggi terkena penyakit degeneratif. Wildman et al (2004), menemukan laki-laki dan perempuan yang mengalami obesitas sentral mempunyai tekanan darah sistol dan diastol dengan rata-rata tinggi.

Berdasarkan uji statistik diperoleh nilai $p$ value $=0,026$ yang menunjukkan ada hubungan yang signifikan antaraobesitas sentral dengan tekanan darah pasien hipertensi. Hal ini juga sejalan dengan penelitian Marisca (2013) yang hasilnya menunjukkan adanya hubungan yang signifikan antara obesitas sentral dengan tekanan darah pasien PJK, dimana PJK juga merupakan salah satu penyakit degeneratif. Obesitas sentral merupakan kondisi kelebihan lemak yang terpusat pada daerah perut (intra-abdomen fat). Lemak yang menumpuk di rongga perut ternyata lebih berbahaya dari lemak yang menumpuk di bagian pinggul dan paha. Penumpukan lemak tersebut terjadi karena kurangnya aktifitas fisik dan pola makan yang salah (Khasanah, 2012).

Banyaknya angka obesitas sentral pada responden penelitian kemungkinan disebabkan tingginya konsumsi lemak dalam tubuh serta kurangnya aktifitas fisik. Konsumsi makanan yang berlebih apabila tidak dibarengi dengan aktifitas fisik yang cukup dapat menyebabkan penumpukan lemak di bagaian tertentu, salah satunya di dalam rongga perut. Apabila terus terjadi penumpukan lemak di dalam tubuh, maka aliran darah menjadi tidak lancar dan jantung akan memompa darah lebih kuat untuk memenuhi kebutuhan nutrisi di setiap jaringan, sehingga tekanan darah menjadi meningkat. Oleh karena itu perlu dilakukannya konsultasi gizi bagi pasien saat berobat ke puskesmas tentang pengaturan makan dalam diet penyakit hipertensi agar pasien dapat mengubah pola makan yang kurang baik menjadi baik dan terkontrol. Untuk meningkatkan informasi pasien mengenai penyakit hipertensi sebaiknya perlu ditambahkan sarana informasi berupa poster maupun leaflet tentang pengaturan makan/ diet penyakit hipertensi agar pasien dapat lebih mudah memahami.

\section{DAFTAR PUSTAKA}

Agustina, Zuhro. 2012. Hubungan Asupan Lemak (Lemak Jenuh, Tak Jenuh, Kolesterol) dan Natrium terhadap Tekanan Darah pada Pasien Hipertensi di POLI Penyakit Dalam RSP Batu. [skripsi]. Program Studi

\section{SIMPULAN}

Pasien masih mempunyai pola makan yang sering mengkonsumsi makanan yang berisiko terjadinya hipertensi seperti mie, roti, biskuit, gorengan dan penggunaan bumbu seperti terasi.Asupan makanan pasien untuk protein hewani kurang baik 52\%, asupan asam lemak jenuhkurang baik berjumlah 53,3\%, asupan kolesterolnya yang baik $50,7 \%$, asupan natrium baik $81,3 \%$ dan asupan seratnya cukup hanya $13,3 \%$.

Responden yang memiliki ukuran lingkar perut dalam batas normal 56\%, sedangkan responden yang memiliki lingkar perut diatas normal 44\%.Pola makan yang berisiko meningkatkan tekanan darah adalah biskuit, telur dan terasi dinyatakan signifikan secara statistik dengan hipertensi.

Asupan makanan yang dinyatakan memiliki hubungan yang signifikan dengan hipertensi yaitu asupan protein hewani, asupan asam lemak jenuh, kolesterol, serat, dan asupan natrium. Obesitas sentral juga memiliki hubungan yang signifikan dengan hipertensi.

\section{SARAN}

Berdasarkan kesimpulan di atas, penulis memberikan beberapa saran antara lain : perlu adanya kerjasama antara dokter dengan ahli gizi supaya pasien dapat dirujuk ke pelayanan konsultasi gizi sehingga pasien lebih memahami tentang diet penyakit hipertensi. Dalam rangka meningkatkan informasi pasien mengenai penyakit hipertensi sebaiknya perlu ditambahkan sarana informasi berupa poster maupun leaflet tentang pengaturan makan/diet penyakit hipertensi. Sarana informasi berupa poster yang ditempel di ruang tunggu atau leaflet yang diberikan kepada pasien setelah konsultasi sehingga pasien lebih memahami informasi terkait penyakit hipertensi terlebih mengenai pemberian diet, sehingga pasien dapat dapat memahami dietnya dan dapat menerapkan diet yang telah dianjurkan terkait dengan penyakit hipertensi.

Ilmu Gizi Fakultas Kedokteran Universitas Brawijaya.

Almatsier, Sunita. 2009. Prinsip Dasar Ilmu Gizi. Jakarta: PT Gramedia Pustaka Utama. 
Apriany, Rista Emiria Afrida. 2012. Asupan Protein, lemak Jenuh, Natrium, Serat, dan IMT terkait dengan Tekanan Darah Pasien Hipertensi di RSUD Tugurejo Semarang. Semarang: Program Studi Ilmu Gizi Univesitas Diponegoro Semarang.

Astawan, Made dan Wresdiyati, Tutik. 2004. Diet Sehat dengan Makanan Berserat. Solo : Penerbit Tiga Serangkai.

AS, Muhammadun, 2010.Hidup Bersama Hipertensi Seringai Darah Tinggi Sang Pembunuh Sekejap. Yogyakarta: In-Noobs.

Azwar, Achdiat, dan Arizal. 2011. Penyakit Diusia Tua. Jakarta: Buku Kedokteran EGC.

Departemen Kesehatan RI. 2006. Pharmaceutical Care Untuk Penyakit Hipertensi. Jakarta :Direktorat Bina Farmasi Komunitas Dan Klinik Ditjen Bina Kefarmasian Dan Alat Kesehatan. 73 halaman.A Pustaka.

Handriani, Kristanti. 2009. Penyakit Akibat Kelebihan dan Kekurangan Vitamin, Mineral dan Elektrolit. Jakarta.

Sutanto Priyio,Hastono. .2007. Analisis Data Kesehatan.Depok: Fakultas Kesehatan Masyarakat Universitas Indonesia.

Infokes. 2007. Penyakit Hipertensi dan Pengobatannya. Informasi Kesehatan. Tersedia di http://infokes.com. Diakses tanggal 4 Desember 2014.

Katulistiwa, Nisa Azza. 2013. Proses Terjadinya Kaitannya Antara Peranan Zat Gizi dan Penyakit Degeneratif (Hipertensi). Tersedia di http://azzakatulistiwafkm10.web.unair.ac.id.Diakses tanggal 16 Januari 2015.

Kemenkes. 2013. Riset Kesehatan Dasar 2013. Jakarta: Penelitian dan Pengembangan.

Khasanah, Nur. 2012. Waspadai Beragam Penyakit Degeneratif Akibat Pola Makan. Yogyakarta : Laksana.

Kurniawan, Anie. 2002. Gizi Seimbang untuk Cegah Hipertensi. Seminar Hipertensi Mahasiswa Fakultas Kedokteran YARSI, 21 September 2002. http://www.gizi.net.

Marisca, Firda Ayu. 2013. Hubungan Asupan Zat Gizi dan Obesitas Sentral terhadap Tekanan Darah pada Pasien Janung Koroner di Poli Penyakit Dalam RSUD Abdul Moloek Provinsi Lampung. Lampung: Politeknik Kesehatan Tanjung Karang.

Mubarak, Wahid Iqbal. 2009. Promosi Kesehatan.Jogjakarta : Graha Ilmu.

Muliyati, Syam A,SirajuddinS. 2011. Hubungan Pola Konsumsi natrium dan Kalium serta Aktifitas fisik dengan Kejadian Hipertensi pada pasien Rawat Jalan di RSUP Dr. WAhidin SH.Media Gizi Masyarakat Indonesia Vol 1 No 1 Agustus 2011.

Notoadmodjo, Soekidjo. 2010. Metodologi Penelitian Kesehatan. Jakarta: Rineka Cipta.

Nugraheni, Suryandari, dan Aruben. 2008. Pengendalian Faktor Determinan Sebagai Upaya Penatalaksanaan Hipertensi Ditingkat Puskesmas [Skripsi]. Semarang: Fakultas Kesehatan Masyarakat Universitas Diponegoro.

Prakoso, Rifqy Akbar. 2012. AWAS KOLESTEROL ! Panduan Hidup Sehat Bebas Kolesterol Jahat. Yogyakarta: Aulya Publishing. 144 halaman

Putra,2010, Hubungan Pendidikan dan Pekerjaan Klien Hipertensi dengan Penatalaksaan Terapi. Diet di Wilayah Puskesmas Lapai kecamatan Nanggola Padang Tahun 2010. Program Studi DIII Keperawatan Padang, Stikes Mercubakti Jaya.

Riskesdas. 2007. Laporan Hasil Riset Kesehatan Dasar (Riskesdas). Jakarta: Kementerian Kesehatan RI.

2013. Laporan Hasil Riset Kesehatan Dasar (Riskesdas). Jakarta: Kementerian Kesehatan RI.

Saban,dkk (2013), Hubungan Pola makan dengan Kehjadian hipertensi pada Lansia di klinik Rawat Jalan di RS Derah Kota Tidore kepulauan, e-Ners, Perhimpunan Ahli Anatomi Indonesia Manado bekerjasama dengan Fakultas Kedokteran Universitas Sam Ratulangi Manado.

Sutanto. 2010. CEKAL (Cegah dan Tngkal) Penyakit Modern (Hipertensi, Stroke, Jantung, Kolesterol, dan Diabetes). Yogyakarta: C.V Andi Offset.

Widyaningrum, Siti. 2012. Hubungan Konsumsi Makanan Dengan Kejadian Hipertensi Pada Lansia [Skripsi]. Jember: Fakultas Kesehatan Masyarakat Universitas Jember.

Wahyuningsih, Retno. 2013. Penatalaksanaan Diet Pada Pasien. Yogyakarta: Graha Ilmu.

WHO. 2002. The World Health Report 2001. Reducing risk, promoting healthy life.http://who.int/whr/2012.Diakses pada 20 November 2014.

------. 2013. A Global Brief On Hypertasion. Geneva: World Health Organization.

World Hypertension League. 2013. How Definition Hypertension. http://www.worldhypertensionleague.org. Diakses tanggal 10 Desember 2014. 